\title{
Amerykański system penitencjarny a poziom inkarceracji weteranów wojennych
}

\section{Streszczenie}

W Stanach Zjednoczonych osadzonych w zakładach karnych jest około 2,2 mln osób. Utrwalił się pogląd, że jest to wynik zbyt surowego systemu wymierzania kar związany z wprowadzeniem polityki bezwzględnej nietolerancji dla narkotyków. Wyroki odsiadują nie tylko członkowie gangów czy handlarze narkotyków, inkarceracja dotyczy również weteranów wojennych. W 2012 r. z powyższej liczby osadzonych penalizacja dotknęła 181,5 tys. byłych mundurowych, zwłaszcza uczestników ostatnich wojen. To głównie weterani pozbawieni stałego zatrudnienia, dachu nad głową lub uzależnieni, zmagający się z problemami natury psychologicznej. Zjawisko jest o tyle niepokojące, że weterani jako grupa uprzywilejowana pod względem socjalnym, osłony medycznej czy edukacji posiadają wszelkie możliwości i narzędzia do tego, aby nie wchodzić w konflikt z prawem. Weterani jako byli żołnierze, zdyscyplinowani i doskonale znający przepisy karne, szkoleni z zasad etyki i prawa humanitarnego konfliktów zbrojnych, z praktycznego punktu widzenia nie powinni łamać zasad dyktowanych przez wymiar sprawiedliwości. Wizerunek byłego funkcjonariusza publicznego, pełniącego służbę na rzecz własnego kraju, kłóci się zupełnie ze statystykami penitencjarnymi. Wydarzenia ostatnich lat pokazały, że służba wojskowa, zwłaszcza w rejonie konfliktu może się stać obosiecznym mieczem, a weterani stanowić mogą zagrożenie dla społeczeństwa.

Słowa kluczowe: amerykańscy weterani, wymiar sprawiedliwości, inkarceracja, system penitencjarny

\section{American prison system and incarceration rate of war veterans}

\begin{abstract}
There are about 2.2 million prisoners in the USA. It is generally viewed that this number is a result of a too severe penal system connected with the introduction of the absolute intolerance for drug crimes policy. But not only gang members and drug dealers are doing time in prison, this system also applies to war veterans. In 2012, there were 181,500 veterans
\end{abstract}


behind bars, especially participants of the recent wars. Most of them face problems with addiction or struggle with permanent unemployment, homelessness or psychological disorders. This phenomenon is alarming because veterans as a privileged group have a social, medical, education cover and all capabilities not to break the law. Veterans as former soldiers, disciplined and well familiar with criminal law, who received ethics and international humanitarian law training courses, from practical point of view should not break the rules stated by the legal system. The image of former veterans who served their country, totally disagree with penitentiary statistics. Recent years have shown that military service, especially in the area of conflict, may become a double-edged sword, and in fact veterans may pose a threat to society.

Keywords: American veterans, justice, incarceration, prison system

\section{Amerykański system penitencjarny}

Niejednokrotnie w życiu weteranów mają miejsce zdarzenia, których skutkiem jest naruszenie obowiązującego w Stanach Zjednoczonych prawa. To uwikłanie ma różne przyczyny, przebieg i skutki, które szerzej przedstawię $\mathrm{w}$ dalszej części rozdziału. Warto jednak wcześniej zwrócić uwagę na kilka czynników regulujących amerykański system penitencjarny. Obecnie w Stanach Zjednoczonych funkcjonuje ponad 5 tys. zakładów karnych (w tym prywatnych) ${ }^{1}$, w których osadzonych jest łącznie około 2,2 mln osób ${ }^{2}$ (4,5 raza więcej niż w 1980 roku), co pozycjonuje Stany

1 Idea więziennego biznesu narodziła się po wojnie secesyjnej i wyzwoleniu niewolników na Południu, wówczas stosunkowo szybko nastąpił deficyt siły roboczej, zwłaszcza w rolnictwie. Więźniowie wynajmowani byli przez farmerów za skromne wynagrodzenie do prac w polu. Rozkwit prywatnego więziennictwa nastąpił za czasów Ronalda Reagana. Walka z narkotykami spowodowała przepełnienie zakładów karnych i zainicjowała powstawanie nowych - prywatnych. Pierwszy z nich, w pełni nowoczesny zakład powstał w Teksasie w 1984 r., dziś jest ich ok. 264. Obecnie głównymi graczami na rynku są korporacje penitencjarne: Corrections Corporation of America (CCA) oraz The GEO Group. CAA jest największym tego typu przedsiębiorstwem, notowanym na nowojorskiej giełdzie, posiada 66 placówek, w których przebywa 91 tys. więźniów. W 2011 r. przychody sięgnęły 1,73 mld USD, a zysk netto przekroczył $162 \mathrm{mln}$ USD. W ciągu ostatnich 10 lat firma przeznaczyła na lobbing prawie 17,5 mln USD. GEO Group jest drugą co do wielkości prywatną firmą z branży penitencjarnej, posiada 65 placówek z miejscami dla 65 tys. więźniów. Jest notowana na giełdzie, jej przychody w $2011 \mathrm{r}$. wyniosły 1,6 mld USD, a zysk netto sięgnął $98,5 \mathrm{mln}$ USD. Wydatki GEO Group na lobbing to 2,5 mln USD w ciągu ostatnich 8 lat. W sierpniu $2016 \mathrm{r}$. Departament Sprawiedliwości Stanów Zjednoczonych wydał komunikat o planowanym, stopniowym wycofywaniu się ze współpracy z prywatnymi korporacjami penitencjarnymi. Argumentem przemawiającym za taką decyzją był brak efektywności ekonomicznej oraz spadek bezpieczeństwa przebywających tam więźniów. Po ogłoszeniu informacji wartość giełdowa akcji spółki CCA spadła o 35 proc., a GEO Group o 39 proc.

2 Economic Perspectives on Incarceration and the Criminal Justice System, Office of the President of the United States, April 2016, s. 3, https://www.whitehouse.gov/sites/default/files/page/files/20160423_ cea_incarceration_criminal_justice.pdf, dostęp: 15.01.2017. 
Zjednoczone na stanowisku więziennego lidera (25 proc. światowej populacji więźniów) $)^{3}$. Zalegalizowały prywatne więzienia 33 amerykańskie stany, wzrost osadzonych w tego rodzaju placówkach w latach 1990-2009 wyniósł 1600 proc. Pod koniec 2010 r. w niepaństwowych placówkach penitencjarnych przebywało 8 proc. więźniów (128 tys. osadzonych). Programy pozwalające na zatrudnienie więźniów w firmach komercyjnych ${ }^{4}$ wprowadziło 37 stanów. W 2014 r. w momencie aresztowania jedna trzecia sprawców była bezrobotna. Przestępstwa związane z narkotykami w 31 stanach karane są obligatoryjnym pozbawieniem wolności. Do więzienia w ciągu pięciu lat od jego opuszczenia wraca 77 proc. osób ${ }^{5}$. Cechą charakterystyczną amerykańskiego wymiaru sprawiedliwości są tzw. zwielokrotnione wyroki, które są alternatywą kary śmierci i formą moralnego zadośćuczynienia dla rodziny ofiary. W 31 amerykańskich stanach obowiązuje kara śmierci. W 2012 r. wydatki amerykańskiego systemu penitencjarnego sięgnęły $274 \mathrm{mld}$ USD, co stanowi 74-procentowy wzrost w porównaniu z $1993 \mathrm{r}^{6}{ }^{6}$. Co istotne, armia amerykańska posiada własne zakłady penitencjarne. Największe z nich znajdują się pod jurysdykcją instytucji wojskowej United States Army Corrections Command. Zaliczyć do nich można m.in. United States Disciplinary Barracks ${ }^{7}$ (Fort Leavenworth w Kansas), Midwest Joint Regional Correctional Facility ${ }^{8}$ (Fort Leavenworth w Kansas) czy też Northwest Joint Regional Correctional Facility (Fort Lewis w Waszyngtonie). Istnieją również placówki karne

3 S. Gorman, Webb Says U.S. Has 5 Percent of World's Population, 25 Percent of its "Known" Prisoners, http://www.politifact.com/virginia/statements/2014/dec/15/jim-webb/webb-says-us-has-5-percentworlds-population-25-pe/, dostęp: 10.01.2017.

4 Do korporacji wykorzystujących pracę więźniów należą m.in.: McDonalds, TWA, Sprint, AT\&T, ToysRUs, IBM, Boeing, Motorola, Microsoft, Dell, Compaq, Revlon, Pierre Cardin, Intel, General Electric, Chevron, American Express.

5 A. Breitwieser, D.W. Schanzenbach, G. Nantz, L. Bauer, M. Mumford, R. Nunn, Twelve Facts about Incarceration and Prisoner Reentry, The Hamilton Project, October 2016, s. 8, https://www.brookings. edu/wp-content/uploads/2016/10/thp_20161020_twelve_facts_incarceration_prisoner_reentry.pdf, dostęp 15.01.2017.

6 Economic Perspectives on Incarceration and the Criminal Justice System, Office of the President of the United States, April 2016, s. 7, https://www.whitehouse.gov/sites/default/files/page/files/20160423_ cea_incarceration_criminal_justice.pdf, dostęp: 15.01.2017.

7 Jest to najstarsze wojskowe więzienie, powstałe w $1847 \mathrm{r}$., przebudowane w $2002 \mathrm{r}$. To jedyny wojskowy zakład karny o zaostrzonym rygorze, odbywają tam karę więźniowie skazani na co najmniej 10 lat pozbawienia wolności, również za przestępstwa przeciwko bezpieczeństwu narodowemu. W placówce tej przebywają m.in. Hasan Akbar (kara śmierci za zabicie dwóch amerykańskich oficerów i ranienie 14 innych w 2003 r.), Nidal Hasan (kara śmierci za zabicie 12 żołnierzy i ranienie 30 innych podczas strzelaniny w bazie Fort Hood w 2009 r.), Robert Bales (dożywocie za zabicie 11 marca 2012 r. 16 afgańskich cywilów w Kandaharze), Chelsea Manning (35 lat więzienia za ujawnienie portalowi WikiLeaks ok. 250 tys. tajnych dokumentów amerykańskiego wywiadu). Ponadto w United States Disciplinary Barracks wyrok odbywali m.in. Charles Graner, skazany za tortury na więźniach w Abu Ghraib oraz William Calley, skazany za udział w masakrze ludności cywilnej w wiosce Mỹ Lai 16 marca 1968 r., podczas wojny wietnamskiej.

8 Jest to wojskowy zakład karny, w którym odbywają karę osadzeni skazani maksymalnie na 10 lat pozbawienia wolności lub tacy, którzy oczekują na proces. 
przeznaczone dla poszczególnych rodzajów sił zbrojnych oraz takie, które znajdują się poza terytorium Stanów Zjednoczonych w amerykańskich bazach wojskowych ${ }^{9}$. Niestety częścią powyższego systemu są również weterani, skazani za przestępstwa drobne jak i ciężkie zbrodnie, osadzeni w więzieniach i aresztach, niektórzy z wieloletnimi wyrokami, bez szans na resocjalizację.

Przedstawiciele amerykańskiego wymiaru sprawiedliwości oraz specjaliści zajmujący się systemem penitencjarnym mają problem z oszacowaniem rzeczywistej skali przestępstw popełnianych przez weteranów, gdyż na poziomie lokalnym i stanowym instytucje nie gromadzą takich danych ${ }^{10}$. Ponadto należy zaznaczyć, że statystyka więziennictwa jest w Stanach Zjednoczonych dość zawiła. Wyroki są orzekane przez federalne, stanowe i lokalne szczeble sądownictwa, a osadzeni przebywają w zakładach karnych zarządzanych na poziomach niekoniecznie zgodnych ze szczeblem, na którym zapadł wyrok ${ }^{11}$. Weterani nie stanowią dużego odsetka osadzonych.

Tabela 1. Liczba osadzonych w amerykańskich więzieniach i aresztach w poszczególnych latach (1978-2012)

\begin{tabular}{|c|c|c|c|c|}
\hline Rok & Liczba dorosłych obywateli & Liczba osadzonych & Więzienia & Areszty \\
\hline 1978 & 157810300 & 465700 & 307300 & 158400 \\
\hline 1985 & 176370700 & 756600 & 502500 & 254100 \\
\hline 1998 & 201576800 & 1899700 & 1307200 & 592500 \\
\hline 2004 & 220832100 & 2211100 & 1497100 & 714000 \\
\hline 2012 & 241419000 & 2314900 & 1570400 & 744500 \\
\hline
\end{tabular}

Źródło: opracowanie własne na podstawie J. Bronson, A. Carson, M.E. Noonan, M. Berzofsky, Veterans in Prison and Jail, 2011-2012, Bureau of Justice Statistics, U.S. Department of Justice, 2015, https://www.bjs. gov/content/pub/pdf/vpj1112.pdf, dostęp: 29.12.2016.

Prekursorem zasady „prawa i porządku” był Richard Nixon, który zaostrzył prawo karne ze względu na serię rewolt w latach 1965-1968. Drastyczny wzrost przestępczości nastąpił ponownie w latach 80. i 90. ub.w., co wynikało z tzw. „wojny z narkotykami”. Rzeczona wojna oznaczała bezwzględną nietolerancję dla narkotyków (zero tolerance) i karanie wszystkich naruszających ustawodawstwo antynarkotykowe. Znaczący wpływ na to miała uchwalona w 1986 r. ustawa o przeciwdziałaniu nadużywaniu

9 Jedyne amerykańskie więzienie wojskowe w Europie znajduje się w bazie wojskowej Coleman Barracks w Sembach w Niemczech (United States Army Corrections Facility - Europe). Ponadto placówki tego rodzaju zlokalizowane są m.in. w Camp Hansen w Japonii i Camp Humphreys w Korei Południowej.

10 S. Stock, L. Wagner, D. Paredes, F. Escamilla, J. Carroll, Veterans Behind Bars, http://www.nbcbayarea. com/investigations/Veterans-Behind-Bars-166063656.html, dostęp: 31.12.2016.

11 S.G. Kozłowski, Ameryka współczesna. Pejzaż polityczny i społeczno-gospodarczy, Lublin 2008, s. $123-124$. 
narkotyków (Anti-Drug Abuse Act) ${ }^{12}$. Zdaniem ustawodawców wysokie kary miały odstraszyć potencjalnych przestępców. Wzrost osadzonych spowodowany był także podpisaniem w $1994 \mathrm{r}$. przez prezydenta Billa Clintona ustawy wprowadzającej karę dożywocia dla recydywistów skazanych po raz trzeci (Three Strikes Law), nawet za drobne przewinienia. Tym samym w wielu przypadkach orzekane kary były nieproporcjonalne lub wręcz niesprawiedliwe. W 2015 r. Clinton przyznał jednak, że była to decyzja, która problem pogłębiła, a nie go naprawiła ${ }^{13}$. Wskazują na to również dane FBI z corocznego raportu dotyczącego przestępczości. W 2015 r. dokonano 1197704 przestępstw z użyciem przemocy (wzrost o 3,9 proc. w porównaniu z 2014 r.), natomiast przestępstw związanych z mieniem (property crimes) było 7993 631. Liczba morderstw wzrosła o 10,8 proc., gwałtów o 6,3 proc., napadów o 4,6 proc., rabunków o 1,4 proc. Ogólnie w 2015 r. dokonano 10,8 mln aresztowań związanych z różnymi naruszeniami prawa ${ }^{14}$.

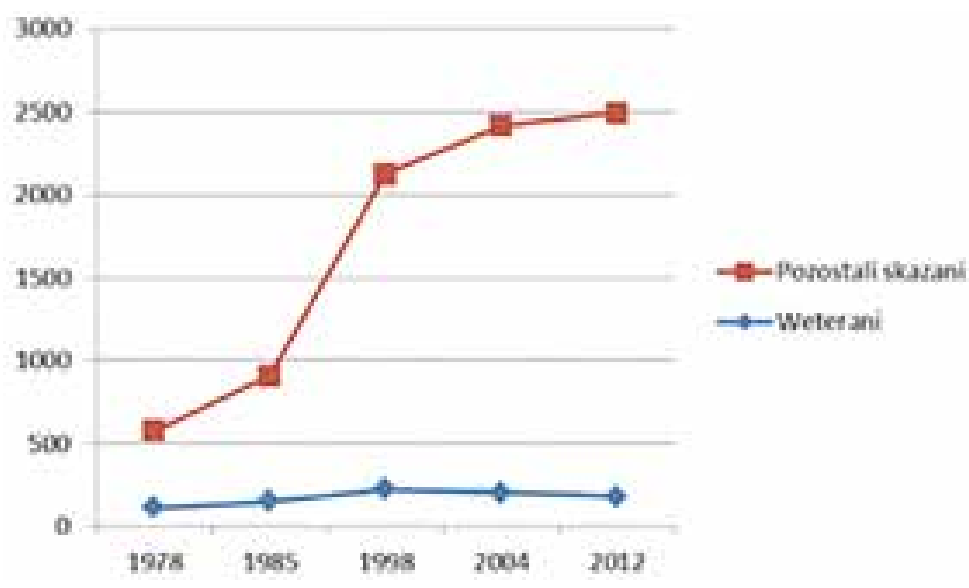

Rysunek 1. Wskaźnik liczby skazanych weteranów do pozostałych osadzonych odbywających karę pozbawienia wolności w zakładach karnych w latach 1978-2012

Źródło: opracowanie własne na podstawie J. Bronson, A. Carson, M.E. Noonan, M. Berzofsky, Veterans in Prison and Jail, 2011-2012, Bureau of Justice Statistics, U.S. Department of Justice, 2015, https://www.bjs. gov/content/pub/pdf/vpj1112.pdf, dostęp: 29.12.2016.

12 S.G. Kozłowski, Ameryka współczesna. Pejzaż polityczny i społeczno-gospodarczy, Lublin 2008, s. $125-126$.

13 J. Byrnes, Clinton: „I Signed a Bill that Made the Problem Worse, and I Want to Admit it”, http:// thehill.com/blogs/blog-briefing-room/news/248160-clinton-i-signed-a-bill-that-made-the-problemworse-and-i-want, dostęp: 8.01.2017.

14 About Crime in the U.S. (CIUS), https://ucr.fbi.gov/crime-in-the-u.s/2015/crime-in-the-u.s.-2015/ home, dostęp: 15.01.2017. 


\section{Inkarceracja weteranów}

Po wojnie w Wietnamie liczba weteranów naruszających prawo stopniowo wzrastała, aż do rekordowego wówczas 1985 r., gdy jeden na pięciu osadzonych w zakładach karnych miał za sobą służbę wojskową. W 1988r. ponad połowa weteranów, u których zdiagnozowano zespół stresu pourazowego, przyznało, że byli oni aresztowani. Natomiast jedna trzecia $\mathrm{z}$ nich odbywało karę pozbawienia wolności więcej niż raz. Jeszcze w 1998 r. w amerykańskich więzieniach i aresztach przebywało 225 tys. weteranów. Ponad połowa z nich odsiadywała wyroki za przestępstwa z użyciem przemocy. 20 proc. osadzonych brało wcześniej czynny udział w walkach podczas wojny wietnamskiej lub I wojny w Zatoce Perskiej ${ }^{15}$. Wśród weteranów I wojny w Zatoce jeden na czterech byłych żołnierzy ma za sobą epizod związany z odbywaniem kary w więzieniu. W 2004 r. 46 proc. weteranów odsiadujących wyrok w więzieniach federalnych i 15 proc. w stanowych zostało zatrzymanych za przestępstwa związane z narkotykami. Natomiast ponad 25 proc. byłych żołnierzy w momencie zatrzymania było pod wpływem środków odurzających ${ }^{16}$. Dane z 2007 r. pokazują, że około 3 proc. wszystkich amerykańskich weteranów popadło $\mathrm{w}$ konflikt $\mathrm{z}$ wymiarem sprawiedliwości. Natomiast 23 proc. $^{17}$ weteranów zostało skazanych za przestępstwa seksualne ${ }^{18}$. Główną przyczyną łamania prawa był brak stabilizacji życiowej, zaburzenia natury psychologicznej, przemoc w rodzinie, nadużywanie alkoholu oraz zażywanie nielegalnych substancji. W wypadku weteranów Gulf War Era II ${ }^{19} 9$ proc. z nich co najmniej raz było aresztowanych od momentu powrotu z misji. W latach 2011-2012 ogólny wskaźnik inkarceracji weteranów

15 Ch.J. Mumola, Veterans in Prison or Jail, Bureau of Justice Statistics, U.S. Department of Justice, 2000, https://www.bjs.gov/content/pub/pdf/vpj.pdf, dostęp: 28.12.2016.

16 S.S. Bush, Psychological Assessment of Veterans, Oxford University Press, New York 2014, s. 374.

17 M. Apuzzo, 23\% of jailed veterans are sex offenders, http://www.deseretnews.com/article/660222515/ 23-of-jailed-veterans-are-sex-offenders.html, dostęp: 31.12.2016.

18 Coroczny wysoki wskaźnik molestowania i gwałtów dokonanych przez żołnierzy i byłych żołnierzy spowodował, że w lutym 2015 r. przygotowano projekt ustawy, na mocy której Departament Obrony zobowiązany będzie do opublikowania fotografii oraz danych żołnierzy skazanych za przestępstwa seksualne. Tym samym mundurowi dołączyli do ogólnokrajowego rejestru skazanych za tego rodzaju przestępstwa. Ustawa została podpisana przez prezydenta Obamę w czerwcu tego samego roku.

19 Na potrzeby danych statystycznych zostały wypracowane przez Departament Spraw Weteranów oraz Departament Pracy Stanów Zjednoczonych określenia odnoszące się do chronologicznych przedziałów czasowych, w których amerykańscy żołnierze pełnili służbę, niezależnie od miejsca. Gulf War Era II datuje się od września 2001 r. do chwili obecnej, Gulf War Era I od sierpnia 1990 do sierpnia 2001 r., Vietnam Era od sierpnia 1964 do kwietnia 1975 r., Korean War od lipca 1950 do stycznia 1955 r., World War II od grudnia 1941 do grudnia 1946r., World War I od kwietnia 1917 do listopada 1918 r., Other service periods lub Peacetime określa służbę żołnierzy we wszystkich innych przedziałach czasowych. Weterani są sklasyfikowani tylko na podstawie ich jednego (ostatniego) wskazanego wyżej okresu służby. Weterani Gulf War Era II to wszyscy żołnierze, którzy pełnili służbę w Afganistanie od października 2001 r., w Iraku od marca 2003 r. lub w obu tych lokalizacjach. 
w Stanach Zjednoczonych wynosił 855 na 100 tys. byłych wojskowych i był niższy od współczynnika występującego w pozostałej części społeczeństwa (968 na 100 tys.). Jednakże weterani częściej skazywani byli za przestępstwa z użyciem przemocy (64 proc.) niż pozostali osadzeni ( 52 proc.), natomiast wyroki, jakie otrzymywali były wyższe ${ }^{20}$. Co jest istotne, 55 proc. byłych żołnierzy przebywających w zakładach karnych miało $\mathrm{w}$ różnym etapie swojego życia problemy natury psychicznej i emocjonalnej ${ }^{21}$. Prawie połowa weteranów osadzonych w więzieniach ( 48 proc.) i aresztach (44 proc.) służyła w wojsku mniej niż trzy lata, natomiast odpowiednio 25 proc. i 31 proc. brało czynny udział w walce na polu bitwy.

Ostatnie rządowe badanie ${ }^{22}$ dotyczące liczby weteranów przebywających w więzieniach i aresztach zostało przeprowadzone w $2012 \mathrm{r}$. przez biuro statystyczne amerykańskiego wymiaru sprawiedliwości (Bureau of Justice Statistics, BJS) ${ }^{23}$ podległe Departamentowi Sprawiedliwości (Department of Justice). Poprzednią oficjalną analizę przeprowadzono w 2004 r. Całkowita liczba weteranów odbywających wówczas karę pozbawienia wolności wynosiła 206,5 tys., co stanowiło 9 proc. wszystkich więźniów w amerykańskich zakładach karnych. W tym samym okresie wojna w Iraku i Afganistanie dopiero zaczynała zbierać swoje żniwo, a weterani wymienionych wojen byli już obecni w więzieniach stanowych $(3,7$ proc.) i federalnych $(4,5 \text { proc. })^{24}$. W dokumencie nie przedstawiono danych dotyczących uczestników operacji Enduring Freedom, Iraqi Freedom oraz New Dawn osadzonych w aresztach. Z raportu przedstawionego w 2015 r. przez Departament Sprawiedliwości Stanów Zjednoczonych wynika, że w latach 2011-2012 w więzieniach i aresztach przebywało łącznie 181,5 tys. ${ }^{25}$ byłych żołnierzy (8 proc. osadzonych w amerykańskich zakładach karnych $)^{26}$. W latach 2001-2012 roku uczestnicy OIF/OEF/OND

20 M. Zottarelli, New Data Shows Fewer Veterans Behind Bars, https://www.swords-to-plowshares. org/2016/01/11/new-data-shows-fewer-veterans-behind-bars, dostęp: 28.12.2016.

21 Wśród osadzonych niezwiązanych z wojskiem wskaźnik ten wynosił 43 proc.

22 Raport powstał na podstawie wyników badań wykonanych w ramach National Inmate Survey (NIS). Metodologia badań przewidziała przeprowadzenie ankiety w 233 stanowych i federalnych więzieniach, 358 aresztach i 15 innych obiektach penitencjarnych (w tym wojskowych), w okresie od lutego $2011 \mathrm{r}$. do maja 2012 r. Przedsięwzięcie zostało zrealizowane przez amerykański think tank RTI International. Ankiety przeprowadzono na grupie 100567 więźniów (41 822 osadzonych w więzieniach stanowych i federalnych, $58745 \mathrm{w}$ aresztach).

${ }_{23}$ The United States Bureau of Justice Statistics (BJS) jest agencją federalną powstałą 27 grudnia 1979 r. Zadaniem biura jest zbieranie, analizowanie i publikowanie danych statystycznych dotyczących przestępczości.

24 M.E. Noonan, Ch.J. Mumola, Veterans in State and Federal Prison 2004, Bureau of Justice Statistics, U.S. Department of Justice, May 2007, https://www.bjs.gov/content/pub/pdf/vsfp04.pdf, dostęp: 08.01.2017.

25 Z czego 131,5 tys. weteranów w więzieniach i 50 tys. w aresztach.

26 J. Bronson, A. Carson, M.E. Noonan, M. Berzofsky, Veterans in Prison and Jail, 2011-2012, Bureau of Justice Statistics, U.S. Department of Justice, December 2015, https://www.bjs.gov/content/pub/pdf/vpj1112.pdf, dostęp: 28.12.2016. 
stanowili łącznie 13 proc. wszystkich weteranów osadzonych w więzieniach oraz 25 proc. przebywających w aresztach ${ }^{27}$. Powyższe dane wskazują na ogólny spadek liczby weteranów znajdujących się w izolacji28. Pokazują to także dane zebrane w $1978 \mathrm{r}$., wówczas weterani stanowili 19 proc. amerykańskiego społeczeństwa, 24 proc. z nich przebywało w więzieniach, a 25 proc. w aresztach. W 2012 r. było to odpowiednio 9 proc. (populacja), 8 proc. (więzienia stanowe i federalne) oraz 7 proc. (areszty) ${ }^{29}$. Szczegóły przedstawia tabela 2.

Tabela 2. Liczba weteranów w więzieniach i aresztach w latach 1978-2012

\begin{tabular}{|c|c|c|c|c|c|}
\hline Rok & Liczba weteranów & Więzienia & Procent osadzonych & Areszty & Procent osadzonych \\
\hline 1978 & 29984000 & 73100 & 23,8 & 39900 & 25,2 \\
\hline 1985 & 27857000 & 100200 & 19,9 & 54400 & 21,4 \\
\hline 1998 & 25062000 & 156400 & 12,0 & 69300 & 11,7 \\
\hline 2004 & 23427600 & 140000 & 9,4 & 66500 & 9,3 \\
\hline 2012 & 21230900 & 131500 & 8,4 & 50000 & 6,7 \\
\hline
\end{tabular}

Źródło: opracowanie własne na podstawie J. Bronson, A. Carson, M.E. Noonan, M. Berzofsky, Veterans in Prison and Jail, 2011-2012, Bureau of Justice Statistics, U.S. Department of Justice, 2015, https://www.bjs. gov/content/pub/pdf/vpj1112.pdf, dostęp: 29.12.2016.

W 2012 r. prawie 99 proc. wszystkich skazanych weteranów stanowili mężczyźni. Średnia wieku osadzonych w aresztach wynosiła 43 lata, 27 proc. było w wieku 18-34 lata, natomiast 19 proc. w wieku 55 lat i powyżej. W wypadku weteranów odbywających karę w więzieniach średnia wieku wynosiła 49 lat, 13 proc. było w wieku 18-34 lata, natomiast 33 proc. było w wieku 55 lat i powyżej. Szczegółowe dane przedstawia tabela 3 , na potrzeby komparatystyczne odniosłem się również do środowiska cywilnego.

Koncentrując się na więziennych statystykach dotyczących weteranów pokolenia 9/11 warto zaznaczyć, że średnia wieku przebywających w więzieniach wynosiła w 2012 r. 30 lat, natomiast $w$ aresztach 28 lat. Prawie połowa $\mathrm{z}$ nich w momencie skazania nie była w związku małżeńskim, zaś jedna trzecia była po rozwodzie. Szczegóły zawarłem w poniższym zestawieniu, w którym uwzględniłem również poziom wykształcenia, rodzaj sił zbrojnych, w których weteran służył, rodzaj przestępstwa oraz długość wyroku.

27 Liczba weteranów wojny w Afganistanie przebywających w więzieniach wyniosła 5 tys. (15,9 proc. osadzonych weteranów) oraz 3,4 tys. przebywająca w aresztach ( 23,3 proc. osadzonych weteranów). W wypadku weteranów $z$ Iraku było to odpowiednio 8,1 tys. ( 25,5 proc.) oraz 6 tys. ( 41,5 proc.).

28 Liczba weteranów odsiadujących wyroki w więzieniach spadła od 2004 r. o 6 proc. (8,5 tys.), natomiast $\mathrm{w}$ aresztach o 25 proc. (16,5 tys.).

29 Wskaźnik weteranów osadzonych w zakładach karnych wynosił w 2012 r. 855 na 100 tys., pozostałych grup społecznych 968 na 100 tys. 
Tabela 3. Wiek oraz płeć weteranów i cywilów osadzonych w amerykańskich więzieniach i aresztach

\begin{tabular}{|l|c|c|c|c|}
\hline \multicolumn{5}{|c|}{ WETERANI } \\
\hline \multicolumn{1}{|c|}{ Wiek } & Więzienia & Procent 0sadzonych & Areszty & Procent osadzonych \\
\hline $18-24$ & 3300 & 2,5 & 4100 & 8,5 \\
\hline $25-34$ & 13700 & 10,5 & 9000 & 18,6 \\
\hline $35-44$ & 27900 & 21,4 & 10100 & 20,9 \\
\hline $45-54$ & 42500 & 32,7 & 15800 & 32,6 \\
\hline $55-64$ & 30900 & 23,8 & 7900 & 16,4 \\
\hline $65-<$ & 11800 & 9,1 & 1400 & 3,0 \\
\hline Mężczyźni & 130100 & 98,9 & 48400 & 96,8 \\
\hline Kobiety & 1400 & 1,1 & 1600 & 3,2 \\
\hline \multicolumn{1}{|c|}{ Wiek } & Więzienia & Procent 0sadzonych & Areszty & Procent 0sadzonych \\
\hline 18-24 & 165300 & 13,6 & 161200 & 27,8 \\
\hline 25-34 & 410000 & 33,8 & 208000 & 35,9 \\
\hline $35-44$ & 342000 & 28,2 & 118300 & 20,4 \\
\hline $45-54$ & 220100 & 18,1 & 73700 & 12,7 \\
\hline $55-64$ & 62900 & 5,2 & 15500 & 2,7 \\
\hline $65-<$ & 12600 & 1,0 & 2200 & 0,4 \\
\hline Mężczyźni & 1213100 & 92,7 & 578900 & 86,6 \\
\hline Kobiety & 95100 & 7,3 & 89900 & 13,4 \\
\hline
\end{tabular}

Źródło: opracowanie własne na podstawie J. Bronson, A. Carson, M.E. Noonan, M. Berzofsky, Veterans in Prison and Jail, 2011-2012, Bureau of Justice Statistics, U.S. Department of Justice, 2015, https://www.bjs. gov/content/pub/pdf/vpj1112.pdf, dostęp: 29.12.2016.

Tabela 4. Charakterystyka penitencjarna weteranów pokolenia 9/11 osadzonych $\mathrm{w}$ amerykańskich więzieniach $\mathrm{i}$ aresztach $\mathrm{w} 2012 \mathrm{r}$.

\begin{tabular}{|l|c|c|}
\hline \multicolumn{1}{|c|}{ Wyszczególnienie } & Więzienia & Areszty \\
\hline Szacowana liczba więźniów & 15800 & 10500 \\
\hline \multicolumn{2}{|c|}{ STAN CYWILNY } \\
\hline Kawaler / Panna & $46,3 \%$ & $48,5 \%$ \\
\hline Żonaty / Mężatka & $16,7 \%$ & $21,9 \%$ \\
\hline Wdowiec / Wdowa & $1,6 \%$ & $0,9 \%$ \\
\hline Rozwiedziony / Rozwiedziona & $28,8 \%$ & $19,6 \%$ \\
\hline Separacja & $5,2 \%$ & $8,8 \%$ \\
\hline \multicolumn{2}{|c|}{ WYKSZTALCENIE } \\
\hline Bez dyplomu szkoły średniej & $23,0 \%$ & $15,6 \%$ \\
\hline Ukończona szkoła średnia & $18,1 \%$ & $29,3 \%$ \\
\hline Ukończona szkoła pomaturalna & $39,5 \%$ & $37,2 \%$ \\
\hline Ukończony college lub uczelnia wyższa & $19,3 \%$ & $17,9 \%$ \\
\hline
\end{tabular}




\begin{tabular}{|c|c|c|}
\hline Wyszczególnienie & Więzienia & Areszty \\
\hline \multicolumn{3}{|c|}{ RODZAJ SIt ZBROJNYCH } \\
\hline Siły powietrzne & $10,5 \%$ & $7,9 \%$ \\
\hline Wojska lądowe & $55,0 \%$ & $54,9 \%$ \\
\hline Korpus marines & $17,3 \%$ & $18,9 \%$ \\
\hline Marynarka wojenna & $19,6 \%$ & $19,0 \%$ \\
\hline Straż wybrzeża & $1,5 \%$ & $1,0 \%$ \\
\hline \multicolumn{3}{|c|}{ RODZAJ POPEŁNIONEGO PRZESTĘPSTWA } \\
\hline Na tle seksualnym & $38,7 \%$ & $11,5 \%$ \\
\hline Z użyciem przemocy & $32,2 \%$ & $22,7 \%$ \\
\hline Związane z mieniem & $11,2 \%$ & $19,9 \%$ \\
\hline Związane z narkotykami & $7,8 \%$ & $16,3 \%$ \\
\hline Jazda pod wpływem alkoholu/środków odurzających & $2,4 \%$ & $6,2 \%$ \\
\hline Inne & $7,8 \%$ & $23,3 \%$ \\
\hline \multicolumn{3}{|c|}{ WYMIAR KARY } \\
\hline Tymczasowe aresztowanie & $0,0 \%$ & $57,5 \%$ \\
\hline Mniej niż 1 rok & $2,9 \%$ & $20,6 \%$ \\
\hline Od 1 do 4 lat & $27,2 \%$ & $14,8 \%$ \\
\hline Od 5 do 19 lat & $47,5 \%$ & $6,0 \%$ \\
\hline 20 lat i więcej & $17,7 \%$ & $0,0 \%$ \\
\hline Dożywocie & $4,8 \%$ & $0,7 \%$ \\
\hline Kara śmierci & $0,0 \%$ & $0,4 \%$ \\
\hline
\end{tabular}

Źródło: opracowanie własne na podstawie J. Bronson, A. Carson, M.E. Noonan, M. Berzofsky, Veterans in Prison and Jail, 2011-2012, Bureau of Justice Statistics, U.S. Department of Justice, 2015, https://www.bjs. gov/content/pub/pdf/vpj1112.pdf, dostęp: 29.12.2016.

Dla wielu weteranów wojny w Iraku i Afganistanie były nie tylko epizodem w służbie wojskowej. Żołnierze część wojny przywieźli ze sobą do domu, w formie obrażeń psychicznych. William B. Brown nazwał nadmierną czujność, depresję, frustrację, agresję, koszmary nocne, alkohol - bagażem, jaki weterani z Iraku i Afganistanu cały czas noszą przy sobie po powrocie $\mathrm{z}$ wojny ${ }^{30}$. Te konflikty jak żaden inny niosły ze sobą wyjątkowe rany fizyczne i psychiczne. Schorzenia psychiczne, takie jak zespół stresu pourazowego (Post Traumatic Stress Disorder, PTSD) i traumatyczny uraz mózgu (Traumatic Brain Injury, TBI) stały się wizytówkami tych wojen oraz w przeważającej większości przyczyniły się do konfrontacji weteranów z wymiarem sprawiedliwości i trudności z funkcjonowaniem w otaczającej ich rzeczywistości. Doświadczenia wojenne potrafią nieść spustoszenie w psychice żołnierza, frustracja i agresja wywołana

30 W.B. Brown, From War Zones to Jail: Veteran Reintegration Problems, "Justice Policy Journal” 2011, Vol. 8, No. 1, s. 9. 
obrazami wojny niszczą życie nie tylko żołnierza, ale wszystkich jego bliskich ${ }^{31}$. Czym jest konflikt zbrojny, bardzo obrazowo przedstawia David L. Smith, pisząc, że „wojna to zmiażdżone ciała i pomieszane umysły. To ściskający trzewia odór rozkładających się zwłok, nadpalonego ciała i fekaliów. To gwałty, choroby i wysiedlenia. To coś przerażającego, coś, co przekracza granice ludzkiego pojmowania" ${ }^{32}$. Poziom stresu, na jaki narażeni byli uczestnicy wojen w Iraku i Afganistanie przedstawia w swojej analizie ${ }^{33}$ Spinning the Bottle: A Comparative Analysis of Veteran-Defendants and Veterans Not Entangled in Criminal Justice prof. W.W. Brown, socjolog z Western Oregon University. Uświadamia czytelnikowi, że 88,5 proc. amerykańskich weteranów podczas działań bojowych widziało zwłoki albo ludzkie szczątki, 83,8 proc. było świadkiem śmierci lub poważnych obrażeń amerykańskiego żołnierza, 40,2 proc. samo doznało poważnego urazu lub zostało rannych w walce, 31,2 proc. zabiło (spowodowało śmierć) przeciwnika, 21,4 proc. brało udział w przenoszeniu/transporcie ludzkich szczątków, 20,9 proc. spowodowało śmierć cywila, 12,8 proc. było bezpośrednio odpowiedzialnych za śmierć dziecka ${ }^{34}$. Według portalu U.S. Medicine, 20 proc. (460 tys.) weteranów wojny w Iraku i Afganistanie cierpi na PTSD lub depresję, podczas gdy 345 tys. weteranów operacji Enduring Freedom, Iraqi Freedom i New Dawn zmaga się z problemami uzależnień ${ }^{35}$.

W ocenie Margaret Noonan, analityka danych w biurze statystycznym Departamentu Sprawiedliwości „weterani nie popadają w konflikt z prawem bezpośrednio po odejściu ze służby, zazwyczaj jest to dość odległy przedział czasu, w którym narasta w nich frustracja, zniechęcenie, depresja i rozczarowanie" ${ }^{36}$. Do tego dochodzi uzależnienie od substancji psychotropowych i uśmierzających ból. Wielu weteranów nie uzyskało odpowiedniej pomocy terapeutycznej lub świadomie z niej zrezygnowało na rzecz zażywania silnych leków, które niejednokrotnie łączyli z alkoholem i narkotykami. Lori Holyfield, profesor socjologii na University of Arkansas, przedstawia w swojej książce przypadek uzależnionego od leków Erica Jasinskiego, weterana

31 D.C. Kelly, S. Howe-Barksdale, D. Gitelson, Treating Young Veterans: Promoting Resilience Through Practice and Advocacy, Springer Publishing Company, New York 2011, s. 168.

32 D.L. Smith, Najbardziej niebezpieczne ze zwierzat. Natura ludzka i przyczyny wojen, Warszawa 2011, s. 29.

33 Prof. William W. Brown w okresie 2008-2010 przeprowadził wywiady z 240 uczestnikami wojen w Iraku i Afganistanie (78 osadzonymi w zakładach karnych i 162 weteranami z 16 stanów Ameryki).

34 J. London, Why Are We Killing Veterans? The Repugnance and Incongruity Of The U.S. Government Executing Psychologically Wounded Veterans, "University of St. Thomas Law Journal" 2014, Vol. 11, No. 2, s. 292.

35 A.M. Boyle, VA Programs Seek to Keep Troubled Veterans Out of Jail, http://www.usmedicine.com/ agencies/department-of-veterans-affairs/va-programs-seek-to-keep-troubled-veterans-out-of-jail/, dostęp: 31.12.2016.

36 M. Wolfe, From PTSD to Prison: Why Veterans Become Criminals, http://www.thedailybeast. com/articles/2013/07/28/from-ptsd-to-prison-why-veterans-become-criminals.html, dostęp: 30.12.2016. 
wojny w Iraku, który spędził w areszcie 27 dni. W liście do swojego adwokata Jasinski pisze: „Odkąd jestem w areszcie, mój stan psychiczny pogorszył się. Mam dostęp do moich leków (zoloft, seraquil, periactim, ambien), ale nawet one przestają na mnie działać. Mimo że biorę seraquil cały dzień, nie mogę zasnąćc"37. Polityka przepisywania substancji uśmierzających ból stała się w placówkach medycznych należących do Departamentu Spraw Weteranów bardzo liberalna. Według Narodowego Instytutu ds. Nadużywania Narkotyków (National Institute on Drug Abuse, NIDA) agencji podległej bezpośrednio Departamentowi Zdrowia i Opieki Społecznej (Department of Health and Human Services) liczba recept wypisywanych weteranom przez lekarzy wojskowych wzrosła w latach 2001-2009 czterokrotnie, do 3,8 $\mathrm{mln}^{38}$. Raport przedstawiony przez organizację Center for Investigative Reporting (CIR) wskazał, że w latach 2001-2012 liczba wydanych przez VA recept wzrosła o 270 proc. $^{39}$. Dostrzegając problem uzależnienia wśród weteranów, Departament Spraw Weteranów w 2012 r. wydał specjalny poradnik poświęcony umiejętnemu korzystaniu z leków opioidowych ${ }^{40}$. Równocześnie nastąpiła znacząca, sięgająca według różnych szacunków 25-50 proc. redukcja wystawiania recept na silne, przeciwbólowe (lecz uzależniające) leki opioidowe ${ }^{41}, \mathrm{w}$ tym m.in. metadon, oksykodon, acetaminofen, hydromorfon i morfinę. Ostatecznie brak dostępu do silnych leków przeciwbólowych niejednokrotnie skutkował jeszcze większymi tragediami weteranó ${ }^{42}$. Jak podaje Departament Spraw Weteranów, 60 proc. uczesników wojen w Iraku i Afganistanie cierpi na chroniczne bóle, zaś 68 tys. z całej populacji byłych mundurowych jest $\mathrm{w}$ różnym stopniu uzależnionych od substancji opioidowych ${ }^{43}$. Permanentny ból rodzący frustrację, tragiczne wspomnienia $\mathrm{z}$ wojny, problemy rodzinne, odczucie braku akceptacji ze strony otoczenia, bezrobocie oraz uzależnienie to część czynników,

37 L. Holyfield, Veterans' Journeys Home: Life After Afghanistan and Iraq, Paradigm Publishers, New York 2011, s. 121.

38 Substance Abuse in the Military, National Institute on Drug Abuse, https://www.drugabuse.gov/publications/drugfacts/substance-abuse-in-military, dostęp: 30.12.2016.

39 A. Glantz, VA's Opiate Overload Feeds Veterans' Addictions, Overdose Deaths, http://cironline. org/reports/vas-opiate-overload-feeds-veterans-addictions-overdose-deaths-5261, dostęp: 08.01.2017.

40 Taking Opioids Responsibly, for Your Safety and the Safety of Others. Patient Information Guide on Opioids for Chronic Pain, VA National Pain Management Program, VA National Center for Ethics in Health Care, http://www.ethics.va.gov/docs/policy/taking_opioids_responsibly_2013528.pdf, dostęp: 08.01.2017.

${ }^{41}$ P. Kime, Justice Dept.'s new \$4M Pledge to Keep Veterans out of Jail, http://www.militarytimes. com/articles/justice-department-reaches-out-to-veterans, dostęp: 31.12.2016.

${ }_{42}$ M. Brunswick, VA Doctors Freely Handed out Pain Medications to Veterans for Years. Then they Stopped. The Results Have Sometimes Turned Tragic, http://www.startribune.com/cut-off-veterans-struggleto-live-with-va-s-new-painkiller-policy/311225761/, dostęp: 8.01.2017.

43 Safe Pain Treatment a Priority at VA San Diego, http://www.sandiego.va.gov/features/pain_treatment.asp, dostęp: 8.01.2017. 
które okazały się dla niektórych weteranów najszybszą drogą do konfliktu z wymiarem sprawiedliwości.

\section{Rodzaje przestępstw}

Doniesienia medialne oraz komunikaty Departamentu Sprawiedliwości ukazują przypadki łamania prawa zarówno przez żołnierzy służby czynnej, jak i weteranów. Coraz częściej pojawiają się informacje o dokonaniu przez weteranów wojen w Iraku i Afganistanie różnych przestępstw, w tym m.in. ciężkiego pobicia ${ }^{44}$, usiłowania zabójstwa $^{45}$, zabójstwa ${ }^{46}$, zabójstwa wielokrotnego ${ }^{47}$, zabójstwa na zlecenie ${ }^{48}$, napastowania $^{49}$, molestowania seksualnego ${ }^{50}$ ( $w$ tym molestowania nieletnich ${ }^{51}$ ), posiadania $^{52}$ i rozpowszechniani ${ }^{53}$ dziecięcej pornografii, gwałtu ${ }^{54}$, oszustwa ${ }^{55}$, przywłaszczenia

${ }_{44}$ S. Healy, War Veteran Jailed for Bashing, http://www.townsvillebulletin.com.au/news/townsville/warveteran-jailed-for-bashing/news-story/06d33febc7b2239ce405460137906664, dostęp: 30.12.2016.

45 J. Morgan, Mall Shooting Suspect is Army Veteran; Served in Afghanistan, http://projects.registerguard. $\mathrm{com} / \mathrm{csp} / \mathrm{cms} / \mathrm{sites} / \mathrm{web} /$ updates/25674689-55/police-eugene-hired-mason-pope.csp, dostęp:30.12.2016.

46 A. Martinez, Former Soldier Sentenced to 50 Years in Prison, http://www.elpasotimes.com/story/ news/crime/2016/11/03/former-soldier-sentenced-50-years-prison/93214910/, dostęp: 30.12.2016.

47 Były Marine zastrzelił sześcioro krewnych. Wśród nich czternastolatkę, http://www.tvn24.pl/wiadomosci-ze-swiata,2/strzelanina-w-stanach-nie-zyje-6-osob,498902.html, dostęp: 30.12.2016.

48 N. Raymond, Ex-U.S. Soldier 'Rambo' Gets 20 Years in Prison in Murder-for-hire Case, http://www. reuters.com/article/us-usa-crime-rambo-idUSKCN0YM2A8, dostęp: 30.12.2016.

49 K. Cloos, Former Fort Carson Soldier Sentenced to Probation for Requesting Oral Sex from School Girls, http://coloradosprings.com/former-fort-carson-soldier-sentenced-to-probation-for-requestingoral-sex-from-school-girls/article/1559000, dostęp: 30.12.2016.

50 J. Bogan, Fort Leonard Wood Drill Sergeant Found Guilty of Sex Assaults, http://www.stripes. com/news/us/fort-leonard-wood-drill-sergeant-found-guilty-of-sex-assaults-1.304772, dostęp: 30.12.2016.

51 Former Ft. Riley Soldier Sentenced to 10 Years for Aggravated Sexual Abuse of Child, https://www. $\mathrm{fbi.gov/contact-us/field-offices/kansascity/news/press-releases/former-ft.-riley-soldier-sentenced-to-}$ 10-years-for-aggravated-sexual-abuse-of-child, dostęp: 30.12.2016.

52 S.J. Campbell, Former Fort Stewart Soldier Sentenced for Child Pornography, http://wsav.com/2016/ 11/10/former-fort-stewart-soldier-sentenced-for-child-pornography/, dostęp 30.12.2016.

53 Army Lieutenant Colonel Sentenced to 20 Years in Prison for Production of Child Pornography Through Social Media and Instant Messaging Apps, https://www.justice.gov/opa/pr/army-lieutenantcolonel-sentenced-20-years-prison-production-child-pornography-through-social, dostęp: 30.12.2016.

54 D. Diaz, Fort Bragg Soldier Charged with Rape of Fellow Soldier, http://edition.cnn.com/2016/04/30/ politics/fort-bragg-soldier-arrested-rape/index.html, dostęp: 30.12.2016.

55 Former Army Captain Convicted of Wire Fraud and Mail Fraud, https://www.fbi.gov/contact-us/fieldoffices/jacksonville/news/press-releases/former-army-captain-convicted-of-wire-fraud-and-mail-fraud, dostęp: 29.12.2016. 
publicznych pieniędzy ${ }^{56}$, kradzież $^{57}$, korupcji ${ }^{58}$, finansowania ${ }^{59} \mathrm{i}$ czynnego wspierania grup terrorystycznych ${ }^{60}$, uprawy marihuany ${ }^{61}$, szpiegostwa ${ }^{62}$, nielegalnej sprzedaży broni i materiałów wybuchowych ${ }^{63}$, przemytu ludzi ${ }^{64}$. Coraz częściej weterani popełniający przestępstwa działają jako „samotne wilki”. W zaplanowanych aktach przemocy popełniają tzw. samobójstwo rozszerzone, które jest domeną m.in. ciężkich zespołów depresyjnych i psychoz. 16 września 2013 r. Aaron Alexis, weteran, który w latach 2007-2011 służył w Marynarce Wojennej, zabił 12 pracowników Naval Sea Systems Command w Waszyngtonie. Sprawca został zastrzelony podczas akcji policji6 ${ }^{65}$ W lipcu 2016r. doszło w Dallas do strzelaniny, w której zginęło pięciu policjantów. Architektem zbrodni był weteran wojny w Afganistanie, szeregowy sił rezerwy, Micah Xavier Johnson ${ }^{66}$. Do jednej z ostatnich masakr doszło 6 stycznia 2017 r. na lotnisku Fort Lauderdale-Hollywood na Florydzie, wówczas weteran z Iraku 26-letni Esteban Santiago zabił pięć osób, a osiem ranił ${ }^{67}$. Dalsze dochodzenia w rzeczonych sprawach wykazały u sprawców poważne zaburzenia psychiczne. Za niektóre zbrodnie weterani skazywani byli na karę śmierci. Od 1930 r. ten wymiar kary wykonano na 160 byłych

56 Two Former U.S. Army Soldiers Sentenced for Stealing \$2.7 Million in Government Funds While Stationed In Saudi Arabia, https://www.justice.gov/usao-ndga/pr/two-former-us-army-soldiers-sentencedstealing-27-million-government-funds-while, dostęp: 30.12.2016.

57 M. Vendituoli, Former Fort Bragg Soldier Sentenced in Military Theft Case, http://www.fayobserver. $\mathrm{com} / \mathrm{military} /$ former-fort-bragg-soldier-sentenced-in-military-theft-case/article_0ed64ea4-4ffc-5d428f72-86ee4077ale3.html, dostęp: 30.12.2016.

58 T.J. Tritten, National Guard Officials, Retires Arrested for Bribery, http://www.stripes.com/news/us/ national-guard-officials-retirees-arrested-for-bribery-1.306083, dostęp: 30.12.2016.

59 Former Army National Guard Member Arrested for Attempting to Provide Material Support to ISIL, https://www.justice.gov/usao-edva/pr/former-army-national-guard-member-arrested-attempting-providematerial-support-isil, dostęp: 30.12.2016.

60 R.A. Serrano, Ex-U.S. Soldier Accused of Joining Al Qaeda-linked Group in Syria, http://articles. latimes.com/2013/mar/29/nation/la-na-syria-arrest-20130329, dostęp: 29.12.2016.

61 B. Donegan, War Veteran with PTSD Faces Life in Prison for Pot, His Wife Calls for Help, http:// truthinmedia.com/exclusive-war-veteran-with-ptsd-faces-life-in-prison-for-pot-his-wife-calls-for-help/, dostęp: 30.12.2016.

62 B. Vergakis, Navy Officer Charged with Espionage in Military Court at Norfolk Naval Station, http:// www.stripes.com/news/us/navy-officer-charged-with-espionage-in-military-court-at-norfolk-navalstation-1.403647, dostęp: 30.12.2016.

${ }^{63}$ Former Infantryman Sentenced for Selling Machine Guns and Explosives, http://www.kfvs12.com/ story/14641361/former-soldier-sentenced-for-selling-machineguns, dostęp: 30.12.2016.

64 Former Ft. Hood U.S. Army Soldier Sentenced to 12 Months in Federal Prison for Alien Smuggling, https://www.ice.gov/news/releases/former-ft-hood-us-army-soldier-sentenced-12-months-federal-prisonalien-smuggling, dostęp: 30.12.2016.

${ }^{6}$ Ch.J. Carter, E. Lavandera, E. Perez, Who is Navy Yard Gunman Aaron Alexis?, http://edition.cnn. com/2013/09/16/us/navy-yard-suspects/, dostęp: 29.12.2016.

66 L.J. Nelson, N. Duara, What we Know about the Dallas Gunman: Army Veteran Reportedly Said He 'Wanted to Kill White People', http://www.latimes.com/nation/la-na-dallas-shooter-20160708-snap-story. html, dostęp: 30.12.2016.

${ }^{67}$ S. Horwitz, C.R. Wootson, Ch. Harlan, Suspect in Fort Lauderdale Shooting "Lost his Mind" in Iraq, Family Says, https://www.washingtonpost.com/news/post-nation/wp/2017/01/07/fort-lauderdale-airportgunman-lost-his-mind-in-iraq-family-says/?utm_term=.7c38b8547b53, dostęp: 7.01.2017. 
żołnierzach (106 skazano za morderstwo, 53 za gwałt, 1 za dezercję) ${ }^{68}$, ostatnia egzekucja odbyła się w $1961 \mathrm{r}^{69}$. Według raportu organizacji Death Penalty Information Center (DPIC) ${ }^{70}$ z 2015 r., wśród ok. 300 wszystkich więźniów skazanych na karę śmierci, 10 proc. stanowią weterani ${ }^{71}$. Tylko prezydent Stanów Zjednoczonych może zmienić rodzaj kary, natomiast egzekucja żołnierza nie może się odbyć bez oficjalnej decyzji i potwierdzenia przez zwierzchnika sił zbrojnych ${ }^{72}$. W ostatnich latach wielu weteranom złagodzono wyrok śmierci na dożywocie ${ }^{73}$. Aktualnie w celi śmierci na wykonanie wyroku oczekuje sześciu weteranów ${ }^{74}$.

Osobny problem stanowią weterani, którzy po odejściu ze służby świadomie związali się z grupami przestępczymi. Niejednokrotnie proces wchodzenia w nielegalne struktury zaczyna się już podczas służby. Gangsterzy w celu rozszerzenia swojego zasięgu i wpływów przeniknęli również do sił zbrojnych Stanów Zjednoczonych ${ }^{75}$. Według ocen Krajowego Centrum Wywiadu ds. Gangów (National Gang Intelligence Center) i Federalnego Biura Śledczego (Federal Bureau of Investigation, FBI) opublikowanych w 2011 r. w raporcie National Gang Threat Assessment członkowie gangów obecni byli podczas operacji militarnych w Iraku i Afganistanie ${ }^{76}$. Niektórzy z nich mają przeszkolenie wojskowe, jako weterani wykorzystują nabyte umiejętności lub nadal pełnią czynną służbę wojskową, głównie w ramach Gwardii Narodowej. Według władz federalnych żołnierze i weterani U.S. Army należą do co najmniej 53 gangów ${ }^{77}$.

68 Statistical Abstract of the United States: 2000, Section 5: Law Enforcement, Courts, and Prisons, U.S. Census Bureau, s. 223, https://www.census.gov/prod/2001 pubs/statab/sec05.pdf, dostęp: 6.01.2017.

69 Ch.J. Carter, Military death row: More than 50 years and no executions, http://edition.cnn.com/ 2013/07/28/justice/military-death-penalty/, dostęp: 6.01.2017.

70 Organizacja Death Penalty Information Center powstała w $1990 \mathrm{r}$. Jest organizacją non-profit, zajmującą się upowszechnianiem na potrzeby opinii publicznej badań i raportów związanych z karą śmierci w Stanach Zjednoczonych. Siedziba organizacji znajduje się w Waszyngtonie, http://www.deathpenaltyinfo. org/, dostęp: 4.01.2017.

71 R.C. Dieter, Battle Scars: Military Veterans and the Death Penalty, Death Penalty Information Center Report, 2015, s. 4, http://deathpenaltyinfo.org/files/pdf/BattleScars.pdf, dostęp: 4.01.2017.

72 D.H. McElreath, L. Keena, G. Etter, E. Stuart, Introduction to corrections, CRC Press, New York 2012, s. 231.

73 Dożywotnie więzienie zamiast kary śmierci zastosowano m.in wobec takich weteranów, jak: Kenneth Parker, James T. Murphy, William Kreutzer, Wade Walker, Jessie Quintanilla, Todd A. Dock, Melvin Turner, Ronnie A. Curtis, Joseph L. Thomas, Curtis A. Gibbs, Jose F. Simoy, http://www.deathpenaltyinfo. org/description-cases-those-sentenced-death-us-military-0, dostęp: 6.01.2017.

74 Ronald Gray (skazany w 1988 r.), Dwight Loving (1989), Hasan Akbar (2005), Andrew Witt (2005), Timothy Hennis (2010), Nidal Hasan (2013), http://www.deathpenaltyinfo.org/description-cases-thosesentenced-death-us-military-0, dostęp: 6.01.2017.

75 S. Robson, FBI Says U.S. Criminal Gangs are Using Military to Spread their Reach, http://www. stripes.com/news/fbi-says-u-s-criminal-gangs-are-using-military-to-spread-their-reach-1.57718, dostęp: 30.12.2016.

76 Raport National Gang Threat Assessment dostępny jest na stronie internetowej FBI, https://www. fbi.gov/stats-services/publications/2011-national-gang-threat-assessment, dostęp: 30.12.2016.

77 Gangs Infiltrate US Military, https://www.rt.com/usa/us-military-gang-members-827/, dostęp: 27.04.2016. 
W amerykańskich bazach wojskowych, również poza granicami państwa, udokumentowano obecność przedstawicieli m.in. takich grup przestępczych, jak Bloods, Crips, Black Disciples, Hells Angels, Latin Kings, Mara Salvatrucha, Nortenos, Vice Lords. FBI wprost określiło to zjawisko jako „zagrożenie dla bezpieczeństwa narodowego". Żołnierze - członkowie gangów - wyjątkowo manifestowali swoją obecność zwłaszcza podczas konfliktów w Iraku i Afganistanie, gdzie na budynkach lub pojazdach wojskowych poprzez graffiti zaznaczali „swoje” terytorium ${ }^{78}$, posługiwali się znanymi sobie sygnałami lub używali gestów i rekwizytów związanych ze światem przestępczym. Grupy przestępcze z premedytacją delegowały swoich przedstawicieli do wojska w celu infiltracji, werbunku, zabójstw, handlu narkotykami, prania pieniędzy lub zapoznania z udzielaniem pierwszej pomocy, bronią, taktyką i systemem walki w terenie zurbanizowanym - które to umiejętności później wykorzystywali w gangsterskich porachunkach. Odnotowano również przypadki kradzieży broni i sprzętu wojskowego, takiego jak gogle noktowizyjne czy kamizelki kuloodporne ${ }^{79}$ nie tylko na potrzeby gangów, ale również meksykańskich karteli narkotykowych ${ }^{80}$. Sprzęt wykorzystywany był następnie przez gangsterów w starciach z policją na ulicach amerykańskich miast. Potwierdzony został również fakt coraz większej aktywności weteranów w gangach motocyklowych ${ }^{81}$. Narracja dotycząca przestępców w strukturach sił zbrojnych wydaje się dość nieprawdopodobna. Są jednak przyczyny takiego stanu rzeczy. W 2013 r. i latach ubiegłych 81,6 proc. z liczącej 33,1 mln populacji młodych osób w Stanach Zjednoczonych nie spełniało kryteriów zdrowotnych, edukacyjnych bądź standardów moralnych do pełnienia służby wojskowej ${ }^{82}$. Ze względu na słabnące zainteresowanie obywateli służbą w wojsku i problemy z rekrutacją, wielu kandydatów otrzymało ze strony Pentagonu tzw. moral waiver, czyli swoiste odpuszczenie win za kryminalną przeszłość ${ }^{83}$. W latach 2003-2007 rzeczoną procedurę zastosowano

78 M. Kennard, Irregular Army: How the U.S. Military Recruited Neo-Nazis, Gang Members, and Criminals to Fight the War on Terror, New York 2012, s. 53.

79 F. Main, FBI Details Threat from Gangs In The Military, http://www.rense.com/general75/abi.htm, dostęp: 27.04.2016.

80 FBI: Soldier Teamed with his Father to Sell Stolen Equipment to Drug Gangs, https://www.armytimes. $\mathrm{com} /$ story/military/2014/08/15/fbi-soldier-teamed-with-his-father-to-sell-stolen-equipment-to-druggangs/14108805/, dostęp: 27.04.2016.

81 R. Tilford, Veterans Joining Gangs Perceived as a Real Problem for the Community and the Nation, http://www.groundreport.com/veterans-joining-gangs-perceived-as-a-real-problem-for-the-communityand-the-nation/, dostęp: 30.12.2016.

82 J.W. Haefner (Lt.Col.), Moral Waivers in Army Recruiting: It Is About Family, Strategy Research Project, United States Army War College, 2013, s. 25.

83 Poza Moral Waiver stosowane były także procedury Tattoo Waiver i Medical Waiver, dla kandydatów posiadających tatuaże i niespełniających kryteriów zdrowotnych. W wypadku Moral Waiver punkty rekrutacyjne automatycznie odrzucały osoby, które dopuściły się więcej niż jednego przestępstwa, zostały skazane za handel narkotykami, przestępstwa seksualne lub tych, którzy spędzili w zakładzie karnym więcej niż rok. Mimo wszystko system selekcji budził wiele kontrowersji, zdarzało się np., że do wojska 
wobec ponad 125 tys. kandydatów ${ }^{84}$. W 2006 r. liczba wcześniej karanych wyniosła 34476 osób (20 proc. wszystkich nowo wcielonych) ${ }^{85}$. W samych tylko wojskach lądowych 11,7 proc. stanowili rekruci notowani wcześniej przez policję $e^{86}$. W $2007 \mathrm{r}$. dzięki Moral Waiver 10 tys. rekrutów rozpoczęło służbę, z czego 2,1 tys. notowanych za poważne przestępstwa, $\mathrm{w}$ tym napady $\mathrm{z}$ bronią $\mathrm{w}$ ręku ${ }^{87}$. Według różnych źródeł szacuje się, że w służbie czynnej powiązanych z gangami jest od 1 proc. ${ }^{88}$ (15 tys.) do 2 proc. $^{89}$ (30 tys.) żołnierzy. Co więcej, ich działania zostały wykryte m.in. w amerykańskich bazach wojskowych w Niemczech, Włoszech, Japonii i Korei Południowej. Zaobserwowano również próby werbunku do gangu nastolatków - członków rodzin personelu wojskowego ${ }^{90}$. Dochodzi także do incydentów wśród służących żołnierzy, którzy demonstrują swoją przynależność do danego gangu. Wojsko zdaje sobie sprawę z problemu, ale walka $\mathrm{z}$ tym zjawiskiem nie będzie łatwa ze względu na stale odradzające się przypadki werbunków i przystąpienia do grup przestępczych żołnierzy wcześniej nieskażonych gangsterstwem. Praktyka rekrutowania do wojska kandydatów z wątpliwą przeszłością nie jest amerykańskiej armii obca. Jeszcze nie tak dawno temu psychologowie wojskowi zalecali werbowanie socjopatów, a nawet osób skazanych za morderstwa, uznając, że przez swoją osobowość mogą stać się idealnymi żołnierzami. W rzeczy samej, wielu wróciło z wojny z orderami za nadzwyczajne męstwo ${ }^{91}$.

W 2008 r. dziennik „New York Times”, korzystając z własnych obliczeń na podstawie analizy raportów policyjnych i sądowych, komunikatów medialnych oraz wywiadów z rodzinami ofiar, podał informację o 121 przypadkach popełnienia morderstw przez amerykańskich weteranów po powrocie z wojen w Iraku i Afganistanie. Według

rekrutowani byli kandydaci skazani za groźby terrorystyczne lub posiadający sądowy zakaz korzystania $\mathrm{z}$ broni palnej.

${ }^{84}$ Moral Waivers and the Military, http://www.nytimes.com/2007/02/20/opinion/20tues1.html?_r=1, dostęp: 27.04.2016.

85 E. Schor, US Army Increases Use of Moral Waivers to Meet Demand for Troops, https://www.theguardian.com/world/2008/apr/21/usa1, dostęp: 4.01.2017.

86 L. Alvarez, Army Giving More Waivers in Recruiting, http://www.nytimes.com/2007/02/14/us/ 14military.html, dostęp: 4.01.2017.

87 G. Mitchell, More than 1 in 10 Army Recruits Now Given "Moral Waivers", http://www.huffingtonpost.com/greg-mitchell/shocker-more-than-1-in-10_b_112400.html, dostęp: 27.04.2016.

88 M. Riopka, Red, White and Gangs: The Problem of Street Gangs in the Military, http://whnt.com/ 2014/06/17/red-white-and-gangs-the-problem-of-street-gangs-in-the-military/, dostęp: 27.04.2016.

89 S. Robson, FBI says U.S. Criminal Gangs are Using Military to Spread their Reach, http://www. stripes.com/news/fbi-says-u-s-criminal-gangs-are-using-military-to-spread-their-reach-1.57718, dostęp: 27.04.2016.

90 C.F. Smith, Gangs in the Military: Forces Conspire to Make Gangs a Worldwide Threat, https://www. academia.edu/483649/Gangs_in_the_Military_Forces_conspire_to_make_gangs_a_worldwide_threat, dostęp: 27.04.2016.

91 D.L. Smith, Najbardziej niebezpieczne ze zwierząt. Natura ludzka i przyczyny wojen, Warszawa 2011, s. 229. 
dziennika, ponad połowa zabójstw została dokonana z użyciem broni palnej, pozostałe dotyczyły pobić, uduszeń i morderstw z użyciem noża. 25 proc. weteranów spowodowało czyjąś śmierć, prowadząc samochód pod wpływem alkoholu bądź narkotyków. Jedna trzecia ofiar to współmałżonkowie, partnerki bądź dzieci weteranów, natomiast jedna czwarta to dawni towarzysze broni ${ }^{92}$. Wśród wymienionych 121 sprawców była jedna kobieta, natomiast zdecydowana większość przed popełnieniem zbrodni nigdy wcześniej nie naruszyła prawa. W większości wypadków przestępstwa te związane były z traumą i towarzyszącym wojnie stresem, nadużywaniem alkoholu i narastającymi problemami rodzinnymi. Diametralna zmiana zachowania po powrocie z wojny, bezsenność, rozdrażnienie, zmienność nastroju, agresja, nadmierne spożywanie alkoholu, zażywanie narkotyków, nierozstawanie się z bronią - to tylko niektóre symptomy zaobserwowane przez rodziny weteranów ${ }^{93}$.

Zdarza się, że w więzieniach przebywają nie tylko weterani, którzy dokonali przestępstwa po zakończeniu służby, ale także żołnierze, którzy dopuścili się zbrodni w rejonie działań wojennych ${ }^{94}$ lub czynu karalnego podczas wykonywania zadań służbowych, np. samowolnego oddalenia (Absent Without Official Leave, AWOL) lub odmowy wykonania rozkazu dotyczącego udziału w misji w Afganistanie ${ }^{95}$. Przestępstwa były popełniane głównie przez najniższy korpus wojskowy. Liczba żołnierzy wojsk lądowych korpusu szeregowych, którzy zostali zwolnieni z armii z powodu przestępstwa lub rażącego naruszenia dyscypliny podwoiła się w latach 2007-2014, z 5,6 tys. do 11 tys. ${ }^{96}$ Liczba oficerów zwolnionych karnie ze służby potroiła się, ze

92 J. Toobin, Why are so Many Veterans on Death Row?, http://www.newyorker.com/news/dailycomment/why-are-so-many-veterans-on-death-row, dostęp: 4.01.2017.

93 D. Sontag, L. Alvarez, Across America, Deadly Echoes of Foreign Battles, http://www.nytimes. com/2008/01/13/us/13vets.html, dostęp: 30.12.2016.

94 Podczas konfliktów w Iraku i Afganistanie kilkukrotnie dochodziło do rażących naruszeń prawa przez żołnierzy amerykańskich, w tym m.in. zbrodni wojennej (19 listopada $2005 \mathrm{r}$. w miejscowości Al-Hadisa w prowincji Al-Anbar w Iraku - 24 zabitych), masakry ludności (11 marca 2012 r. w Kandaharze w Afganistanie - 16 zabitych), torturowania więźniów w Abu Ghraib (marzec 2003 r.), morderstw i gwałtów (12 marca 2006r. w Mahmoudiyah w Iraku - 4 zabitych). W najnowszej historii Ameryki głośne były przypadki dokonywania przez żołnierzy przestępstw uznanych później za zbrodnie wojenne również podczas wojny w Wietnamie. Masakra, która przyczyniła się do spadku poparcia dla działań amerykańskich w Wietnamie miała miejsce 16 marca 1968 r. w wiosce Mỹ Lai. Wówczas amerykańscy żołnierze dokonali rzezi ludności cywilnej, mordując, gwałcąc oraz torturując głównie starszych ludzi, kobiety i dzieci. Według różnych źródeł, zginęło ok. pięciuset osób. Szczegóły wydarzeń opisują M. Bilton, K. Sim w książce Four Hours in Mỹ Lai, wyd. Penguin Books, New York 1993.

95 H. Lee, U.S. Soldier Sentenced to Year in Prison for Refusing to Fight in Afghanistan, https://www. wsws.org/en/articles/2009/08/bish-a18.html, dostęp: 30.12.2016.

96 Po rozpoczęciu działań wojennych w Iraku i Afganistanie wskaźnik żołnierzy wojsk lądowych, którzy zostali zwolnieni za naruszenia prawa, wynosił ok. 9 tys. 
119 w 2010 r. do 387 w 2014 r. ${ }^{97}$. Wskaźnik naruszeń prawa przez żołnierzy pozostałych sił zbrojnych był zdecydowanie niższy ${ }^{98}$, co przedstawiają dane z 2013 r.

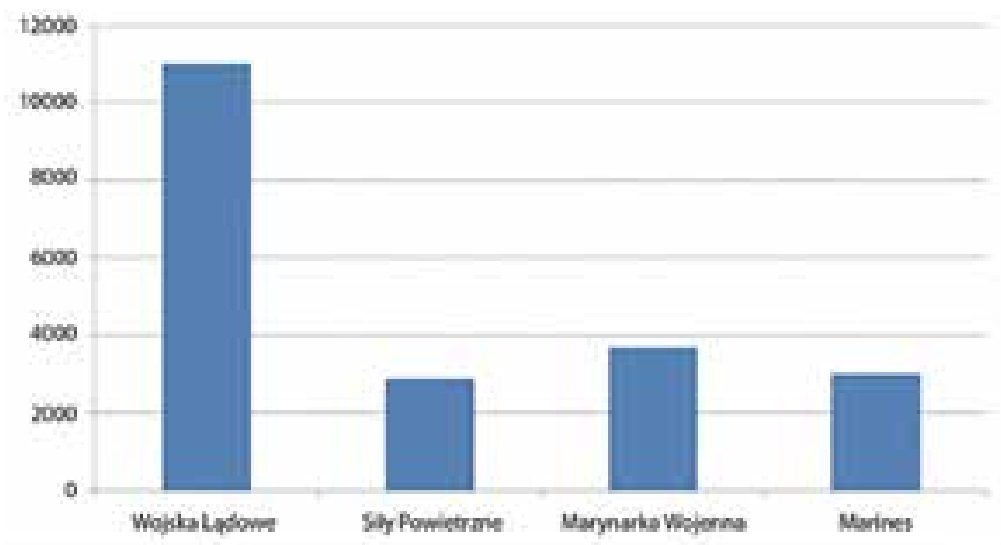

Rysunek 2. Wskaźnik liczby żołnierzy zwolnionych dyscyplinarnie w 2013 r.

Źródło: opracowanie własne na podstawie L.C. Baldor, AP Exclusive: Misconduct forces more soldiers out, http:// bigstory.ap.org/article/ap-exclusive-misconduct-forces-more-soldiers-out, dostęp: 3.01.2017.

Miały na to wpływ przede wszystkim wielokrotne, długotrwałe wyjazdy żołnierzy wojsk lądowych na misje i bezpośredni udział w walkach. Empiryczne doświadczenie wojny bez wątpienia mogło wpłynąć na dalsze czyny żołnierzy. Po drugie, sam udział w misji, nawet „bierny”, np. na stanowisku analityka w sztabie, wiązał się z permanentnym stresem i napięciem, uzupełnianym relacjami żołnierzy z pola walki, co również nie pozostawało obojętne dla osobowości weterana. Po trzecie, był to efekt szybkiego kompletowania pododdziałów piechoty, zastosowania w latach 2003-2007 liberalnej polityki wobec kandydatów ubiegających się o przyjęcie do wojska, m.in. zastosowanie wspomnianego wcześniej Moral Waiver.

97 S. Frizell, U.S. Army Firing More Soldiers for Misconduct, http://nation.time.com/2014/02/15/u-sarmy-firing-more-soldiers-for-misconduct/, dostęp: 2.01.2017.

98 W marynarce wojennej w $2006 \mathrm{r}$. zwolnionych zostało 8,4 tys. marynarzy, w 2013 r. usunięto ich 3,7 tys. Wśród oficerów wskaźnik w latach 2006-2013 utrzymywał się na podobnym poziomie i wynosił od 84 do 107 zwolnień rocznie. W siłach powietrznych w 2002 r. usunięto dyscyplinarnie 4,5 tys. szeregowych oraz 2,9 tys. w 2013 r. W korpusie marines w 2007 r. zwolniono 4,4 tys. żołnierzy, w 2013 r. liczba zwolnień wyniosła 3 tys. 


\section{Sądy dla weteranów}

Z racji coraz większej liczby naruszeń prawa przez weteranów w 2008 r. w amerykańskim wymiarze sprawiedliwości powstał precedens. W Buffalo w stanie Nowy Jork po raz pierwszy powołany został sąd dla weteranów ${ }^{99}$ (Veterans Treatment Court), który tym samym wszedł w skład grupy tzw. sądów skoncentrowanych na rozwiązywaniu problemów (Problem-solving Courts, PSC). Sądy dla weteranów wzorowane są na istniejących już sądach narkotykowych ${ }^{100}$ (Drug Courts), sądach zdrowia psychicznego (Mental Health Courts), sądach przemocy domowej (Domestic Violence Courts), sądach dla społeczności (Community Courts) i mają na celu ścisły nadzór nad sprawcami drobnych przestępstw oraz kierowanie ich na stosowną terapię zamiast do aresztu czy więzienia ${ }^{101}$. Podczas zatrzymania policja ustala, czy sprawca przestępstwa jest weteranem. Jeżeli czyn zabroniony został dokonany z udziałem przemocy, weteran nie zawsze kwalifikuje się do programu przewidzianego przez sąd. Przeważnie uwzględnia się weteranów, którzy dopuścili się przestępstw z kategorii niskiej szkodliwości społecznej. Warunkiem przystąpienia do programu resocjalizacji jest zgoda weterana. Postępowanie obejmuje stosowanie środków probacyjnych w ścisłej współpracy sądów, prokuratur, stróżów prawa, stanowych i lokalnych biur administracji spraw weteranów (State Departments of Veterans Affairs, Vet Centers), Departamentu Pracy, pomocy społecznej oraz innych instytucji służących

${ }^{99}$ Inicjatorem i prekursorem powstania pierwszego w Stanach Zjednoczonych sądu dla weteranów był sędzia Robert Russell. Powiedział wówczas, że „to właśnie do wymiaru sprawiedliwości należy krytyczne spojrzenie na sposób, w jaki najlepiej można pomóc weteranom, sposób, który zapewni weteranom stabilizację po raz kolejny". Za innowacyjne w skali wymiaru sprawiedliwości rozwiązanie został wyróżniony przez ówczesnego sekretarza Spraw Weteranów Stanów Zjednoczonych (United States Secretary of Veterans Affairs) Erica Shinsekiego.

100 Sądom narkotykowym warto poświęcić więcej uwagi, gdyż tworzą najliczniejszą grupę tego rodzaju placówek. Po raz pierwszy powstały w hrabstwie Miami-Dade na Florydzie w 1989 r. w odpowiedzi na rosnącą liczbę przestępstw popełnianych przez mieszkańców pod wpływem narkotyków. Architektami pomysłu utworzenia sądów narkotykowych byli sędziowie i adwokaci: Gerald Wetherington, Herbert Klein, Janet Reno i Bennett Brummer, którzy opracowali system pomocy dla sprawców wykroczeń poprzez kierowanie na stosowne terapie dla uzależnionych. Działania te organizowane są w ścisłej współpracy sądów, prokuratury, stróżów prawa i pomocy społecznej. Według raportu powstałej w $1994 \mathrm{r}$. organizacji National Association of Drug Court Professionals, w 2014 r. w Stanach Zjednoczonych istniało 3057 sądów narkotykowych. Rocznie przed sądem tego rodzaju staje około 120 tys. osób. Powołanie sądów narkotykowych zostało uznane za ogromny sukces amerykańskiego wymiaru sprawiedliwości, gdyż udowodniono ich wysoką skuteczność. Więcej w: D.B. Marlowe, C.D. Hardin, C.L. Fox, Painting the Current Picture. A National Report on Drug Courts and Other Problem-Solving Courts in the United States, National Drug Court Institute, June 2016, http://www.nadcp.org/sites/default/files/2014/Painting\%20the\%20 Current\%20Picture\%202016.pdf, dostęp: 30.12.2016.

${ }^{101}$ Sądy dla weteranów zajmują się głównie byłymi żołnierzami, u których w trakcie lub po zakończeniu służby wojskowej zdiagnozowano schorzenia natury psychicznej, przede wszystkim PTSD, TBI, napady agresji, uzależnienie od narkotyków i alkoholu. 
resocjalizacji i prewencji kryminalnej. Kluczową rolę stanowi program Veterans Justice Outreach (VJO) ${ }^{102}$ prowadzony przez specjalistów z Administracji Zdrowia Weteranów (Veterans Health Administration, VHA) ${ }^{103}$. Warto dodać, że przebieg działań wychowawczo-resocjalizacyjnych, diagnostycznych i profilaktycznych jest zróżnicowany w zależności od lokalizacji sądu dla weteranów i dostosowany do prawa stanowego. Program może trwać od 3 do 24 miesięcy, podczas których odbywa się wiele terapii, warsztatów, szkoleń mających na celu przygotowanie byłych żołnierzy do wejścia na rynek pracy, współpracy z otoczeniem lub radzenia sobie ze stresem. Raz w tygodniu weteran spotyka się z sędzią. Przez cały okres trwania programu odbywają się regularne testy na zawartość narkotyków bądź alkoholu w organizmie. Jeżeli uczestnik programu nie wywiązuje się z zaleceń, sąd może nałożyć na niego karę finansową, wydłużyć okres próby lub skierować do zakładu karnego. Odnotowano wysoką skuteczność środków probacyjnych. Według danych organizacji Justice For Vets $^{104}$ z 2016 r., 66 proc. weteranów ukończyło z powodzeniem programy resocjalizacyjne. Natomiast w 88 proc. sądów dla weteranów odnotowano wyraźny spadek aresztowań. Podobne dane z 2015r. przedstawia Veterans Health Administration, która informowała, że 81 proc. poddanych resocjalizacji nie było ponownie karanych ${ }^{105}$. Odnotowano także 36-proc. spadek zażywania przez weteranów substancji niedozwolonych oraz 44-proc. spadek objawów PTSD. Laurie Harkness, dyrektor programowy VHA, omawiając skuteczność programu przyznała, że „wielu weteranów zamiast odbywać karę, otrzymuje pomoc, jakiej potrzebuje. Jest to znacząca różnica w ich życiu" ${ }^{106}$. Sukcesywnie rozwijają się kolejne placówki, 55 proc. z nich powstało w latach 2011-2012 ${ }^{107}$. Pod koniec grudnia 2014 r. w 33 stanach istniało 220 sądów

102 Veterans Justice Outreach, https://www.va.gov/homeless/vjo.asp, dostęp: 1.01.2017.

103 Veterans Health Administration (VHA) jest jednym z komponentów Departamentu Spraw Weteranów. Poza programem Veterans Justice Outreach (VJO), VHA oferuje program Health Care for Re-entry Veterans (HCRV), którego celem jest pomoc weteranom odbywającym karę pozbawienia wolności w ponownej reintegracji ze społeczeństwem po wyjściu z więzienia. Pomoc oferowana jest poprzez system szkoleń, spotkań oraz warsztatów prowadzonych przez specjalistów oddelegowanych z VHA z zakresu przestrzegania prawa, zatrudnienia, radzenia sobie z agresją i uzależnieniami. Podstawowym jednak celem programu HCRV jest zapobieganie bezdomności wśród weteranów po zakończeniu odbywania przez nich kary.

104 Organizacja zajmująca się szkoleniem pracowników sądów dla weteranów oraz inicjowaniem powstawania kolejnych placówek tego typu, Justice For Vets, http://justiceforvets.org/, dostęp: 31.12.2016.

${ }_{105}$ Przez pierwszy rok działalności przez program przeszło 1,1 tys. weteranów.

106 P. McCarthy, Troubled Veterans Get Treatment, Not Jail, http://c-hit.org/2015/02/15/troubledveterans-get-treatment-not-jail/, dostęp: 1.01.2017.

107 S.M. Strong, R.R. Rantala, T. Kyckelhahn, Census of Problem-Solving Courts, 2012, U.S. Department of Justice, Office of Justice Programs, Bureau of Justice Statistics, October 2016, https://www.bjs. gov/content/pub/pdf/cpsc12.pdf, dostęp: 4.01.2017. 
dla weteranów ${ }^{108}$. W 2016 r. Departament Sprawiedliwości przeznaczył na ich rozwój kolejnych $4 \mathrm{mln} \mathrm{USD}^{109}$. W opinii przeciwników tego rodzaju sądów (w tym niektórych organizacji zajmujących się ochroną praw obywatelskich), traktowanie weteranów jako specjalnej, uprzywilejowanej grupy tworzy dwubiegunowy system wymiaru sprawiedliwości, w którym tylko weterani w tak wyrafinowany sposób dostają drugą szansę na resocjalizację i ponowny powrót do społeczeństwa jako praworządni obywatele. Zdaniem kolejnych, weterani nie powinni być traktowani specjalnie, ponieważ służyli w wojsku jako ochotnicy, z własnej, nieprzymuszonej woli ${ }^{110}$.

Warto jednak zwrócić uwagę na kwestie finansowe. Koszt utrzymania jednego więźnia oscyluje w granicach 30-45 tys. USD rocznie (co możemy porównać z czesnym na dobrej amerykańskiej uczelni), program resocjalizacji oferowany przez sądy dla weteranów to koszt rzędu 6-12 tys. USD rocznie ${ }^{111}$. Według innego źródła, średni miesięczny koszt „kontrolowanej wolności” jednego uczestnika to 420 USD, koszt utrzymania więźnia 2,9 tys. USD ${ }^{112}$. Natomiast prof. A. Bałandynowicz podaje, że w Stanach Zjednoczonych utrzymanie więźnia kosztuje od 10 do 13 razy więcej niż jego monitoring w społeczeństwie ${ }^{113}$. Ponadto istnieje większa szansa, że po zakończeniu programu resocjalizacji weteran uniknie bezrobocia i bezdomności dzięki odpowiedniemu przygotowaniu, szkoleniom i profilaktyce. W więzieniu byłoby to zdecydowanie utrudnione lub wręcz niemożliwe. O krytyce resocjalizacyjnej roli więzienia pisze chociażby norweski socjolog prawa T. Mathiesen. W swojej książce Prison on Trail opisuje, że w praktyce proces modyfikacji osobowości danej jednostki w warunkach więziennych nigdy nie istniał i jest jedynie ideologią i myśleniem życzeniowym ${ }^{114}$.

Penalizacja uderza przede wszystkim w tę część społeczności weteranów wojen w Iraku i Afganistanie, którzy pozbawieni są stałego zatrudnienia, dachu nad głową lub mają problemy z uzależnieniami. Zjawisko jest o tyle niepokojące, że weterani jako grupa uprzywilejowana pod względem socjalnym, osłony medycznej czy edukacji posiadają wszelkie możliwości i narzędzia do tego, aby nie wchodzić w konflikt

108 Veterans Treatment Court Locations, http://justiceforvets.org/veterans-treatment-court-locations, dostęp: 31.12.2016.

109 P. Kime, Justice Dept.s New \$4M Pledge to Keep Veterans out of Jail, http://www.militarytimes. com/articles/justice-department-reaches-out-to-veterans, dostęp: 31.12.2016.

110 K. Shevory, Why Veterans Should Get Their Own Courts, http://www.theatlantic.com/magazine/archive/2011/12/why-veterans-should-get-their-own-courts/308716/, dostęp: 4.01.2017.

${ }^{111}$ E. Delmore, Veterans Can Get Help Instead of Jail Time, http://www.msnbc.com/jansing-co/nowvets-can-get-help-instead-jail-time, dostęp: 31.12.2016.

112 P. McCarthy, Troubled Veterans Get Treatment, Not Jail, http://c-hit.org/2015/02/15/troubledveterans-get-treatment-not-jail/, dostęp: 1.01.2017.

113 A. Bałandynowicz, Probacja: resocjalizacja $z$ udziałem społeczeństwa, Wolters Kluwer Polska, Warszawa 2011, s. 37.

114 T. Mathiesen, Prison on Trial, Waterside Press, United Kingdom, 2006, s. 46. 
z prawem. Co więcej, odchodząc od praworządności, weterani tracą swoje przywileje. Okres odbywania kary pozbawienia wolności wiąże się z czasowym zredukowaniem lub zupełną utratą świadczeń zdrowotnych i socjalnych przyznawanych przez Departament Spraw Weteranów. Dla przykładu, weteran skazany za przestępstwo, który przebywa w zakładzie karnym powyżej 60 dni może mieć obniżoną wypłatę odszkodowania z tytułu niepełnosprawności nawet o połowę. Natomiast świadczenia edukacyjne nie są wypłacane weteranom, którzy popełnili morderstwo. W wypadku emerytów, po 60 dniach zawiesza się wypłatę do momentu zwolnienia weterana z więzienia. Warto jednak dodać, że wszelkie świadczenia przysługujące weteranowi mogą zostać scedowane na współmałżonka, dzieci lub rodziców osadzonego ${ }^{115}$.

Weterani jako byli żołnierze, zdyscyplinowani i doskonale znający przepisy karne, szkoleni z zasad etyki i prawa humanitarnego konfliktów zbrojnych, z praktycznego punktu widzenia nie powinni łamać reguł dyktowanych przez wymiar sprawiedliwości. Wizerunek byłego funkcjonariusza publicznego, pełniącego służbę na rzecz własnego kraju, kłóci się zupełnie ze statystykami penitencjarnymi. Nasuwają się więc dwie interpretacje. Pierwsza dotycząca weteranów, na których inkarcerację wpłynęły problemy natury psychologicznej, silny stres i traumatyczne doświadczenia wojenne. Rzeczona trauma wywarła wpływ bezpośrednio na funkcjonowanie weterana w społeczeństwie i jego relacje z najbliższymi. Drugi wariant stanowią weterani słabiej wykształceni, źle dobrani, „weterani wyobrażeni”, którzy świadomie zeszli na ścieżkę przestępczą. To nieraz członkowie gangów, o zachwianej moralności, dla których służba była odskocznią od codzienności, przygodą pozbawioną znamion patriotyzmu i etyki, co pokazały liczne przypadki Moral Waiver.

Służba wojskowa, zwłaszcza w rejonie konfliktu, z czasem staje się obosiecznym mieczem, a weterani stanowią zagrożenie dla społeczeństwa. Otwarcie powiedział o tym weteran z Iraku Andrew Chambers, odsiadujący wyrok 10 lat więzienia za usiłowanie zabójstwa i inne przestępstwa ${ }^{116}$. Podczas publicznego wystąpienia w ramach konferencji TEDx w zakładzie karnym w Marion (Marion Correctional Institution) w stanie Ohio ${ }^{117}$. Należy przy tym pamiętać, że jedna trzecia weteranów wojen w Iraku i Afganistanie zmaga się z zespołem stresu pourazowego i różnego

115 Veterans Benefits Administration, Incarcerated Veterans, http://www.benefits.va.gov/persona/veteran-incarcerated.asp, dostęp: 3.01.2017.

116 A. Salazar, Judge to soldier: “Your Time in Iraq Makes You a Threat to Society...", http://www.infowars. com/judge-deems-soldier-threat-to-society-after-tours-of-duty-in-iraq/, dostęp: 10.01.2017.

117 Your Time in Iraq Makes you a Threat to Society: Andrew Chambers at TEDx Marion Correctional Salon 2013, https://www.youtube.com/watch?v=X6AYmzunPlQ, dostęp: 10.01.2017. 
typu uzależnieniami. Niedopuszczalna jest zatem ignorancja wobec problemów, jakie dotykają byłych żołnierzy. Częściowym rozwiązaniem wydaje się być modus operandi sądów dla weteranów, które nie tylko dają szansę resocjalizacji i skutecznego powrotu do społeczeństwa, ale także przypominają byłym mundurowym o treści przysięgi wojskowej, jaką wypowiadali, rozpoczynając służbę $e^{118}$.

Inkarceracja 2,2 mln więźniów kosztuje rocznie amerykańskich podatników około 274 mld USD oraz pośrednio obciąża osadzonych, ich rodziny i społeczeństwo. Konsekwencje to nie tylko problem z późniejszym zatrudnieniem, ale także z dostępem do służby zdrowia, zakwaterowaniem czy wyżywieniem. Inwestycje w prewencję czy programy pomocowe i probacyjne wydają się najbardziej właściwe, zważywszy na to, że 77 proc. osadzonych wraca do więzienia po pięciu latach od jego opuszczenia. Odpowiednia praca wychowawczo-resocjalizacyjna w więzieniu pozwoli skazanym znaleźć zatrudnienie oraz ponownie wejść w ramy praworządnego społeczeństwa. Natomiast programy prewencyjne dla młodzieży i edukacja wczesnoszkolna są równie istotne w celu zmniejszenia przestępczości w dłuższej perspektywie.

\section{Bibliografia}

Bałandynowicz A., Probacja: resocjalizacja z udziałem społeczeństwa, Wolters Kluwer Polska, Warszawa 2011.

Boyle A.M., VA Programs Seek to Keep Troubled Veterans Out of Jail, http://www.usmedicine. com/agencies/department-of-veterans-affairs/va-programs-seek-to-keep-troubled-veteransout-of-jail/

Breitwieser A., Schanzenbach D.W., Nantz G., Bauer L., Mumford M., Nunn R., Twelve facts about incarceration and prisoner reentry, The Hamilton Project, October 2016, https:// www.brookings.edu/wpcontent/uploads/2016/10/thp_20161020_twelve_facts_incarceration_prisoner_reentry.pdf

Bronson J., Carson A., Noonan M.E., Berzofsky M., Veterans in Prison and Jail, 2011-12, Bureau of Justice Statistics, U.S. Department of Justice, December 2015, https://www.bjs. gov/content/pub/pdf/vpj1112.pdf

Brown W.B., From War Zones to Jail: Veteran Reintegration Problems, "Justice Policy Journal" 2011, Vol. 8, No. 1.

Bush S.S., Psychological Assessment of Veterans, Oxford University Press, New York 2014.

118 „I, (...), do solemnly swear that I will support and defend the Constitution of The United States against all enemies, foreign and domestic; that I will bear true faith and allegiance to the same; and that I will obey the orders of the President of the United States and the orders of the officers appointed over me, according to the regulations and the Uniform Code of Military Justice. So help me God". 
Byrnes J., Clinton: "I Signed a Bill that Made the Problem Worse, and I Want to Admit it", http://thehill.com/blogs/blog-briefing-room/news/248160-clinton-i-signed-a-bill-thatmade-the-problem-worse-and-i-wantDieter R.C., Battle Scars: Military Veterans and the Death Penalty, Death Penalty Information Center Report, 2015, http://deathpenaltyinfo. org/files/pdf/BattleScars.pdf

Gorman S., Webb Says U.S. Has 5 Percent of World's Population, 25 Percent of its "Known" Prisoners, http://www.politifact.com/virginia/statements/2014/dec/15/jim-webb/webbsays-us-has-5-percent-worlds-population-25-pe/

Haefner J.W. (Lt.Col.), Moral Waivers in Army Recruiting: It Is About Family, Strategy Research Project, United States Army War College, 2013.

Holyfield L., Veterans' Journeys Home: Life After Afghanistan and Iraq, Paradigm Publishers, New York 2011.

Kelly D.C., Howe-Barksdale S., Gitelson D., Treating Young Veterans: Promoting Resilience Through Practice and Advocacy, Springer Publishing Company, New York 2011.

Kennard M., Irregular Army: How the U.S. Military Recruited Neo-Nazis, Gang Members, and Criminals to Fight the War on Terror, New York 2012.

Kozłowski S.G., Ameryka współczesna. Pejzaż polityczny i społeczno-gospodarczy, Lublin 2008.

London J., Why Are We Killing Veterans? The Repugnance and Incongruity of The U.S. Government Executing Psychologically Wounded Veterans, "University of St. Thomas Law Journal" 2014, Vol. 11, No. 2.

Marlowe D.B., Hardin C.D., Fox C.L., Painting the Current Picture. A National Report on Drug Courts and Other Problem-Solving Courts in the United States, National Drug Court Institute, June 2016, http://www.nadcp.org/sites/default/files/2014/Painting\%20the\%20Current\% 20Picture\%202016.pdf

Mathiesen T., Prison on Trial, Waterside Press, United Kingdom, 2006.

McElreath D.H., Keena L., Etter G., Stuart E., Introduction to Corrections, CRC Press, New York 2012.

Mumola Ch.J., Veterans in Prison or Jail, Bureau of Justice Statistics, U.S. Department of Justice, 2000, January 2000, https://www.bjs.gov/content/pub/pdf/vpj.pdf

Noonan M.E., Mumola Ch.J., Veterans in State and Federal Prison, 2004, Bureau of Justice Statistics, U.S. Department of Justice, May 2007, https://www.bjs.gov/content/pub/pdf/vsfp04.pdf

Riopka M., Red, White and Gangs: The Problem of Street Gangs in the Military, http://whnt. com/2014/06/17/red-white-and-gangs-the-problem-of-street-gangs-in-the-military/

Robson S., FBI says U.S. Criminal Gangs are Using Military to Spread their Reach, http:// www.stripes.com/news/fbi-says-u-s-criminal-gangs-are-using-military-to-spread-theirreach-1.57718

Schor E., US Army Increases Use of Moral Waivers to Meet Demand for Troops, https://www. theguardian.com/world/2008/apr/21/usa1

Smith C.F., Gangs in the Military: Forces Conspire to Make Gangs a Worldwide Threat, https:// www.academia.edu/483649/Gangs_in_the_Military_Forces_conspire_to_make_gangs_a_ worldwide_threat 
Smith D.L., Najbardziej niebezpieczne ze zwierzat. Natura ludzka i przyczyny wojen, Warszawa 2011.

Stock S., Wagner L., Paredes D., Escamilla F., Carroll J., Veterans Behind Bars, http://www. nbcbayarea.com/investigations/Veterans-Behind-Bars-166063656.html

Strong S.M., Rantala R.R., Kyckelhahn T., Census of Problem-Solving Courts, 2012, U.S. Department of Justice, Office of Justice Programs, Bureau of Justice Statistics, October 2016, https:// www.bjs.gov/content/pub/pdf/cpsc12.pdf

Veterans Benefits Administration, Incarcerated Veterans, http://www.benefits.va.gov/persona/veteran-incarcerated.asp

Wolfe M., From PTSD to Prison: Why Veterans Become Criminals, http://www.thedailybeast. com/articles/2013/07/28/from-ptsd-to-prison-why-veterans-become-criminals.html

Zottarelli M., New Data Shows Fewer Veterans Behind Bars, https://www.swords-to-plowshares. org/2016/01/11/new-data-shows-fewer-veterans-behind-bars 